\title{
Effect of milk yield characteristics, breed, and parity on success of the first insemination in Dutch dairy cows
}

\author{
C. Inchaisri, ${ }^{,} \dagger^{1}$ H. Hogeveen, ${ }^{*} \ddagger$ P. L. A. M. Vos, ${ }^{*}$ G. C. van der Weijden, ${ }^{*}$ and R. Jorritsma ${ }^{*}$ \\ *Department of Farm Animal Health, Faculty of Veterinary Medicine, Utrecht University, P.O. Box 80151, 3508 TD, the Netherlands \\ †Department of Veterinary Medicine, Faculty of Veterinary Science, Chulalongkorn University, Bangkok, 10330, Thailand \\ łBusiness Economics, Wageningen University, P.O. Box 8130, 6706 KN Wageningen, the Netherlands
}

\section{ABSTRACT}

The objective of this study was to determine the contribution of cow factors to the probability of a successful first insemination (SFI). The investigation was performed with 51,791 lactations from 1,396 herds obtained from the Dutch dairy cow database of the Cattle Improvement Co-operative (CRV). Cows that had the first insemination (AI) between 40 and 150 $\mathrm{d}$ postpartum were selected. The first AI was classified as successful when cows were not reinseminated and either calved between 267 and 295 d later or were culled within 135 to $295 \mathrm{~d}$ after first AI. The lactation curve characteristics of individual lactations were estimated by Wilmink's curve using the test-day milk records from CRV. The lactation curve characteristics (peak milk yield, milk yield at the first-AI date, time of peak yield (PT), and milk persistency) were calculated. Breed, parity, interval from calving to first AI (CFI), lactation curve characteristics, milk production traits, moment of AI related to PT (before or after PT), calf status, month of AI, and month of calving were selected as independent variables for a model with SFI as a dependent variable. A multivariable logistic regression model was used with farm as a random effect. Overall SFI was $44 \%$. The effect of parity on SFI depended on CFI. The first-parity cows had the greatest SFI (0.43) compared with other parities $(0.32-0.39)$ at the same period of CFI before $60 \mathrm{~d}$ in milk (DIM), and cows in parity $\geq 5$ had the least SFI $(0.38-0.40)$ when AI was after 60 DIM. After 60 DIM, extending CFI did not improve SFI in the first-parity cows, but SFI was improved in multiparous cows. Holstein-Friesian cows had lesser SFI (0.37) compared with cross-breed cows (0.39-0.46). Twin and stillbirth calving reduced SFI (0.39) compared with a single female calf $(0.45)$ or a male calf $(0.43)$ calving. The SFI in different months of AI varied and depended on CFI. Cows that received

Received March 5, 2010

Accepted August 3, 2010.

${ }^{1}$ Corresponding author: c.inchaisri@uu.nl
AI before 60 DIM had a lesser SFI, especially in March, June, and July $(0.18,0.35$, and 0.34 , respectively). Artificial insemination before PT reduced SFI (0.39) in comparison with AI after PT (0.44). The effect of milk yield at the first-AI date on SFI varied depending on CFI. After 60 DIM at the same period of CFI, a high level of milk yield at the first-AI date reduced SFI. In conclusion, knowledge of the contribution of cow factors on SFI can be applied to support decision making on the moment of insemination of an individual cow in estrus.

Key words: milk production, lactation curve, first insemination, successful calving

\section{INTRODUCTION}

High reproductive efficiency is an important prerequisite to guarantee profitable dairy production. Several factors, including cow factors and management and environmental factors, are generally known to affect the economical return of a dairy farm. In general, factors such as milk production, BCS, postpartum disorders, breed, parity, DIM, feeding regimens, and seasonality have substantial effects on reproductive efficiency in dairy cows, and these effects have been found to be applicable in the Netherlands (Berry et al., 2003; Tsuruta et al., 2009). Moreover, when milk production has been increased, reproductive performance of dairy cattle has decreased (Huang et al., 2009; Norman et al., 2009). A successful first AI (SFI) is a key in reproductive efficiency, but the probability of conception after the first AI differs from cow to cow (Windig et al., 2005). At least part of the difference between cows is explained by the 305-d milk yield (MY305) or the cumulative milk yield in the early stage of lactation (Kadarmideen et al., 2000; Veerkamp et al., 2001). This observation has been confirmed by other studies, in which characteristics of the lactation curve of an individual cow, such as milk persistency (Muir et al., 2004) and peak milk yield (Kinsel and Etherington, 1998), affect the probability of SFI. In general, the high-producing cows within herds have a low conception rate at the first 
AI (Windig et al., 2005). Moreover, conception rate improves with an increase of DIM (Loeffler et al., 1999; Tenhagen et al., 2003) but decreases when the milk yield produced on the test-day closest to the AI date on conception is greater (Loeffler et al., 1999). Therefore, one may predict that the milk yield around the time of $\mathrm{AI}$ is an important factor determining the success of the AI. Due to the effect of gestation, cumulative milk yield, MY305, or milk persistency is partly dependent on reproductive performance (Olori et al., 1997). Thus, milk yield at the day of first AI (MYFI) and the interval from calving to first AI (CFI) are more suitable as predictors for SFI. Moreover, from a practical perspective, knowledge about the influence of MYFI and CFI on SFI may assist farmers in deciding whether to start or delay the first AI. Hence, it is important to know which factors contribute to SFI and to what extent SFI is influenced by these factors. Although many studies reported on the possible relationship between cow factors and conception rates, no studies showed a modeled SFI using only cow factors that are measurable before first AI. Therefore, the objective was to determine the effects of cow factors, especially those before the first AI postpartum, on the probability of SFI in Dutch dairy cows.

\section{MATERIALS AND METHODS}

\section{Data}

The original data set, consisting of AI and production records of 104,969 lactations following calving in 3,674 herds in 2006, was selected randomly from the database of the Cattle Improvement Co-operative. In general, Dutch farmers use a dry period length of about $2 \mathrm{mo}$ and house these cows separately. Also, feeding is usually adjusted to meet the requirements in the dry period. Many farmers have a close look at individual parturient cows, e.g., by using a separate calving pen. Herds with fewer than 25 lactations in the data set were removed ( $\mathrm{n}=7,942$ lactations). To standardize AI techniques, herds in which not all cows were artificially inseminated by a technician from the Cattle Improvement Co-operative were removed $(\mathrm{n}=9,438$ lactations). Lactations with incomplete data with respect to cow identification, birth date, calving date, AI date, or parity were removed ( $\mathrm{n}=18,290$ lactations). Herds that had at least one cow that was naturally serviced or inseminated for embryo transfer were deleted from the data set because the insemination records were supposedly less reliable ( $\mathrm{n}=1,093$ lactations). Lactations from cows that were artificially inseminated before 40 or after 150 DIM were assumed not representative of normal healthy cows and were removed $(\mathrm{n}=9,028$ lactations). When the interval between 2 AI was less than $10 \mathrm{~d}$, the first AI of that pair was considered as missing. Lactations with only 1 AI without information on culling, death, or a next calving date were removed ( $\mathrm{n}=135$ lactations). Lactations with an aberrant fitted curve (see equation $1 ; \mathrm{n}=489$ lactations) were removed, as described in the next paragraph. Also, lactations with less than 5 test-day milk records $(\mathrm{n}=815$ lactations), with a test-day milk record interval $<14 \mathrm{~d}$ or $>70 \mathrm{~d}$, or with first test-day milk records after 70 DIM ( $\mathrm{n}=2,120$ lactations) were removed because these circumstances are rarely seen in normal healthy cows. Moreover, lactations with a high fluctuation in test-day milk records between test-day interval were removed (n $=826$ cows). Lactations of culled cows were removed when culling took place $<50 \mathrm{~d}$ after the first AI $(\mathrm{n}=$ 537). The obtained cow fertility records were matched with milk production data, and unmatched data were removed ( $\mathrm{n}=110$ lactations). Other lactations were removed after the estimation of the lactation curve if it gave unsatisfactory characteristics, e.g., milk production that was too low and peak time that was too early ( $\mathrm{n}=2,599$ lactations). Finally, a data set of 51,791 lactations from 1,396 herds with $59.2 \pm 0.7$ (mean \pm SE) lactations per herd was used. Of all lactations, $32 \%$ were parity $1,25 \%$ parity $2,17 \%$ parity $3,12 \%$ parity 4 , and $15 \%$ parity 5 or greater. The breeds of the cows were $100 \%$ Holstein-Friesian (HF; $63 \%$ of lactations), 50 to $<100 \%$ HF ( $32 \%$ of lactations), 51 to $100 \%$ Dutch Red-and-White (4\% of lactations), and other breeds (1\% of lactations).

\section{Lactation Curve}

A lactation curve for each lactation was modeled using the test-day milk recording data of the cow. A combined exponential and linear model was chosen to depict the shape of the lactation curve (Wilmink, 1987):

$$
\mathrm{MY}_{\mathrm{ti}}=\mathrm{a}_{\mathrm{i}}+\mathrm{b}_{\mathrm{i}} \times \mathrm{t}_{\mathrm{i}}+\mathrm{c}_{\mathrm{i}} \times \exp \left(-0.05 \times \mathrm{t}_{\mathrm{i}}\right),
$$

where $\mathrm{MY}_{\mathrm{ti}}$ is milk $(\mathrm{kg})$ on day t postpartum of cow $\mathrm{i}$, a is the scaling factor estimating production at time zero, $b$ is the rate of descent after the peak, and $c$ is the rate of ascent to the peak. The initial values in different parities of $\mathrm{a}, \mathrm{b}$, and $\mathrm{c}$ given the age at calving (mo) were obtained from an earlier study (Wilmink, 1987). Parameter estimates including a, b, and c for individual lactation were obtained using the GaussNewton method in the nonlinear procedure (PROC NLIN) of SAS (version 9.2, SAS Inst. Inc., Cary, NC). A lactation curve was classified as nonaberrant and 
remained in the data set when the estimated values for $\mathrm{b}$ and $\mathrm{c}$ were negative, resulting in the well-known convex parabola milk production curve. Also, lactation curves with a decreasing production curve due to the lack of a somewhat lesser test-day milk record early in lactation were classified as nonaberrant as long as the first AI was after the first test-day milk record. These curves had a negative value for $\mathrm{b}$ and a positive value for $\mathrm{c}$ in the modeled lactation curve. Based on the estimated lactation curve parameters, the 4 lactation curve characteristics peak time $\left(\mathrm{PT}_{\mathrm{i}}\right)$, peak yield $\left(\mathrm{PY}_{\mathrm{i}}\right)$, $\mathrm{MYFI}_{\mathrm{i}}$, and persistency $\left(\mathrm{MPER}_{\mathrm{i}}\right)$ were calculated for individual lactations of cow $\mathrm{i}$ as follows:

$$
\begin{aligned}
& \mathrm{PT}_{\mathrm{i}}=-20 \log \left(20 \mathrm{~b}_{\mathrm{i}} / \mathrm{c}_{\mathrm{i}}\right), \\
& \mathrm{PY}_{\mathrm{i}}=\mathrm{a}_{\mathrm{i}}+\mathrm{b}_{\mathrm{i}} \times \mathrm{PT}_{\mathrm{i}}+\mathrm{c}_{\mathrm{i}} \times \exp \left(-0.05 \times \mathrm{PT}_{\mathrm{i}}\right), \quad[3 \\
& \mathrm{MYFI}_{\mathrm{i}}=\mathrm{a}_{\mathrm{i}}+\mathrm{b}_{\mathrm{i}} \times \mathrm{CFI}_{\mathrm{i}}+\mathrm{c}_{\mathrm{i}} \times \exp \left(-0.05 \times \mathrm{CFI}_{\mathrm{i}}\right),[4] \\
& \mathrm{MPER}_{\mathrm{i}}=\left(\mathrm{MY}^{280_{\mathrm{i}}}-\mathrm{MY90}_{\mathrm{i}}\right) / 190,
\end{aligned}
$$

where $\mathrm{PT}_{\mathrm{i}}$ is DIM at $\mathrm{PY}_{\mathrm{i}}$ and $\mathrm{CFI}_{\mathrm{i}}$ is interval between calving and first AI date of cow i. The variables MY280 and $\mathrm{MY} \mathrm{O}_{\mathrm{i}}$ are the milk yield of cow i at 280 and $90 \mathrm{~d}$ postpartum, respectively. For cows with a decreasing lactation curve, the first test-day milk record was used as $\mathrm{PT}_{\mathrm{i}}$ and $\mathrm{PY}_{\mathrm{i}}$.

\section{Definition of a Successful First Al}

Cows that delivered a calf with a gestation length between 267 and $295 \mathrm{~d}$ after a single first AI were classified as having an SFI. Cows that were culled during lactation had a successful first AI when they were not reinseminated after the first $\mathrm{AI}$ and when they were culled between at least $135 \mathrm{~d}$ (95th percentile of interval from the first to the second AI calculated from the data set) and $295 \mathrm{~d}$ after first AI (the maximum length of gestation). All other cows with at least one AI were classified as having a nonsuccessful first AI.

\section{Statistical Analyses}

The following measures were calculated to obtain descriptive statistics and Pearson correlations coefficients for continuous variables or Spearman rank correlations coefficients for categorical variables (r): parity, breed, milk production measures (MY305, 305-d protein yield, and 305-d fat yield), lactation curve characteristics (PY, PT, MPER, and MYFI), and reproductive performances (CFI, calving date, first AI date, time of AI related to $\mathrm{PT}$, and calf status).
Statistical analyses were carried out to determine the association between SFI and independent variables, using SAS (PROC GLIMMIX) with binary distribution and logit link. Farm was added in the model as a random effect:

$$
\begin{gathered}
\operatorname{logit}\left(\mathrm{p}_{\mathrm{ij}}\right)=\beta_{0}+\beta_{1} \mathrm{X}_{1 \mathrm{i}}+\ldots+\beta_{\mathrm{k}} \mathrm{X}_{\mathrm{ki}}+\lambda_{\mathrm{j}}, \\
\mathrm{p}_{\mathrm{ij}}=\left(\frac{\mathrm{SFI}_{\mathrm{i}} \mid \lambda_{\mathrm{j}}}{1-\mathrm{SFI}_{\mathrm{i}} \mid \lambda_{\mathrm{j}}}\right)
\end{gathered}
$$

where $\mathrm{p}_{\mathrm{ij}}$ is the comparison between the probability of the success and nonsuccess of the first AI of cow $\mathrm{i}$ on farm $\mathrm{j}, \beta_{0}$ is the estimated intercept, and the regression coefficients of $\log$ odds ratio $\left(\beta_{1}\right.$ to $\left.\beta_{\mathrm{k}}\right)$ were estimated for each independent factor $\left(\mathrm{X}_{1 \mathrm{i}}\right.$ to $\left.\mathrm{X}_{\mathrm{ki}}\right)$. The $\mathrm{X}_{\mathrm{ki}}$ are the predictor values of an independent variable $\mathrm{k}$ for cow $\mathrm{i}$. The random effect of farm $\mathrm{j}$ is $\lambda_{\mathrm{j}}$, assumed $\lambda_{\mathrm{j}} \sim \mathrm{N}\left(0, \sigma^{2}\right)$, and the relationship between the probability $\mathrm{p}_{\mathrm{ij}}$ and the binary outcome is success of the first $\mathrm{AI}\left[\mathrm{p}\left(\mathrm{SFI}_{\mathrm{ij}}=1\right)\right.$ $=p_{i j}$. Success of the first AI of cow $i$ on farm $\mathrm{j}$ is $\mathrm{SFI}_{\mathrm{ij}}$. Combining equations 6 and 7 , the estimation of $\mathrm{SFI}_{\mathrm{i}}$ adding farm as a random effect and its link function $\left.\left(\mathrm{E}_{\left[\mathrm{SFI}_{\mathrm{ijk}} \mid\right.} \lambda_{\mathrm{j}}\right]\right)$ were analyzed as follows:

$$
\mathrm{E}\left[\mathrm{SFI}_{\mathrm{ijk}} \mid \lambda_{\mathrm{j}}\right]=\frac{1}{1+\exp \left(-\boldsymbol{\beta}_{0}-\mathrm{X}_{1 \mathrm{i}} \boldsymbol{\beta}_{1} \ldots-\mathrm{X}_{\mathrm{ki}} \boldsymbol{\beta}_{\mathrm{k}}-\lambda_{\mathrm{j}}\right)} .
$$

All independent variables were modeled, including breed, parity, calf status after birth, CFI, lactation curve characteristics (PY, PT, MPER, and MYFI), milk production measures (MY305, 305-d protein yield, and 305-d fat yield), month of calving and month of first AI (January to December), and time of AI related to PT. Due to nonnormal distribution of CFI, it was categorized into 3 -wk estrous interval groups of $\leq 60$, 61 to 81,82 to 102,103 to 123 , and $\geq 124$ DIM for the subsequent analysis. Cow breeds were categorized as $100 \%$ HF, 50 to $<100 \%$ HF, 51 to $100 \%$ Dutch Redand-White, and others. Parities were categorized as 1, $2,3,4$, and $\geq 5$. Registered calves from included cows were categorized as female, male, twin, and stillbirth. The AI times related to PT were categorized for AI before or after PT. For categorized variables, all dummy variables were entered. The factors that affected SFI in the univariable analysis $(P<0.15)$ and were not highly correlated $(\mathrm{r}>0.5)$ with other predictors were included in multivariable analysis by stepwise forward regression. Yet, MYFI and AI date were included in the multivariable analysis because they were preferred 
Table 1. Descriptive statistics (mean, 5th and 95th percentile) of the studied variables

\begin{tabular}{lccc}
\hline Variable $^{1}$ & $\mathrm{n}$ & Mean & $\begin{array}{c}5 \text { th; } 95 \text { th } \\
\text { percentiles }\end{array}$ \\
\hline CFI (d) & 51,791 & 87 & $51 ; 136$ \\
CIN (d) & 44,269 & 409 & $336 ; 554$ \\
PY (kg) & 51,791 & 35 & $24 ; 48$ \\
PT (d) & 51,791 & 46 & $17 ; 73$ \\
MPER (kg/d) & 51,791 & -0.07 & $-0.13 ;-0.02$ \\
MYFI (kg) & 51,791 & 33 & $22 ; 45$ \\
MY305 (kg) & 51,791 & 8,542 & 5,$929 ; 11,345$ \\
PROT305 (kg) & 51,791 & 296 & $209 ; 385$ \\
FAT305 $(\mathrm{kg})$ & 51,791 & 370 & $261 ; 486$ \\
\hline
\end{tabular}

${ }^{1} \mathrm{CFI}=$ interval from calving to first $\mathrm{AI}$; $\mathrm{CIN}=$ calving interval; $\mathrm{PY}=$ peak milk yield; $\mathrm{PT}=$ time of peak yield; $\mathrm{MPER}=$ milk persistency; MYFI $=$ milk yield at the first-AI date; MY305 $=305-\mathrm{d}$ milk yield; PROT305 $=305$-d protein yield; FAT305 $=305$-d fat yield.

over other measures for milk production and timing. Other independent variables were entered freely or were removed, using twice the negative of the residual loglikelihood (model deviance), type 3 sums of squares, and the coefficients and error terms of the main effects. Confounding was assessed if the exclusion variables changed the remaining parameter estimates $>10 \%$. Interactions between the remaining parameters (MYFI and CFI, parity and MYFI, parity and CFI, breed and MYFI, breed and CFI, calf status and MYFI, calf status and CFI, month of AI and MYFI, month of AI and CFI, time of AI related to PT and MYFI) were analyzed. A variable remained in the model when its significance level was less than 0.1 and the linearity assumption between log-odds and variables was met. The final model was acceptable when the ratio of the generalized chi-squared was close to one (Brown and Prescott, 1999). The model diagnostics were performed by plotting the residuals against log-odds and the fitted values judged for peculiarities for the final multivariable model. When categorized data were statistically significant, the estimates from the final model were expressed as means of the probabilities of SFI, and pair-wise means comparison between categorized data was carried out with Tukey adjustment at $P<0.05$.

\section{RESULTS}

\section{Data Description}

The overall SFI was $43.7 \%$. Descriptive data and an average of the variables studied are in Table 1. Culling percentage of all cows was $14.3 \%$, and SFI of culled cows was $18.1 \%$. Of all lactations, $0.04 \%$ had a shorter calving interval than $267 \mathrm{~d}$, and $9.5 \%$ had a second AI more than 3 reproductive cycles $(63 \mathrm{~d})$ after the first AI, whereas $7.8 \%$ of calvings were stillbirths, and $2.3 \%$ were twins. In the univariable analysis, the associations
Table 2. Results of the analysis of risk factors for successful first AI from the univariable logistic regression analysis using farm as a random effect in the model ${ }^{1}$

\begin{tabular}{|c|c|c|c|}
\hline Variable $^{2}$ & $\beta$ & SE & $P$-value \\
\hline $\begin{array}{l}\text { Breed } \\
\text { HF } 100 \%\end{array}$ & Ref. $^{3}$ & & $<0.01$ \\
\hline HF 50 to $<100 \%$ & 0.10 & 0.02 & $<0.01$ \\
\hline MRY 51 to $100 \%$ & 0.30 & 0.05 & $<0.01$ \\
\hline Others & 0.42 & 0.08 & $<0.01$ \\
\hline Parity & & & $<0.01$ \\
\hline 1 & 0.21 & 0.03 & $<0.01$ \\
\hline 2 & 0.14 & 0.03 & $<0.01$ \\
\hline 3 & 0.15 & 0.03 & $<0.01$ \\
\hline 4 & 0.08 & 0.03 & 0.01 \\
\hline$\geq 5$ & Ref. & & \\
\hline Calf status & & & $<0.01$ \\
\hline Female & Ref. & & \\
\hline Male & -0.06 & 0.02 & $<0.01$ \\
\hline Twin & -0.23 & 0.06 & $<0.01$ \\
\hline Stillbirth & -0.25 & 0.03 & $<0.01$ \\
\hline Month of calving ${ }^{4}$ & - & - & $<0.01$ \\
\hline Month of $\mathrm{AI}^{4}$ & - & - & $<0.01$ \\
\hline CFI (d postpartum) & & & $<0.01$ \\
\hline$\leq 60$ & -0.22 & 0.03 & $<0.01$ \\
\hline$\overline{61}$ to 81 & -0.05 & 0.03 & $\mathrm{NS}^{5}$ \\
\hline 82 to 102 & -0.007 & 0.03 & NS \\
\hline 103 to 123 & -0.006 & 0.03 & NS \\
\hline$\geq 124$ & Ref. & & \\
\hline $\mathrm{PY}(\mathrm{kg} / \mathrm{d})$ & -0.01 & 0.001 & $<0.01$ \\
\hline $\mathrm{PT}(\mathrm{d})$ & 0.0002 & 0.0005 & NS \\
\hline MPER (kg/d) & -5.13 & 0.26 & $<0.01$ \\
\hline MYFI (kg/d) & -0.013 & 0.001 & $<0.01$ \\
\hline MY305 (kg) & -0.0001 & 0.000005 & $<0.01$ \\
\hline FAT305 (kg) & -0.003 & 0.0001 & $<0.01$ \\
\hline PROT305 (kg) & -0.003 & 0.0002 & $<0.01$ \\
\hline Time of AI & & & $<0.01$ \\
\hline After PT & Ref. & & \\
\hline Before PT & -0.26 & 0.03 & $<0.01$ \\
\hline
\end{tabular}

${ }^{1}$ Estimated coefficient ( $\beta$ ), SE for the coefficient, and significance level are given for each cow-specific risk factor.

${ }^{2} \mathrm{HF}=$ Holstein-Friesian; MRY $=$ Dutch Red-and-White; CFI = interval from calving to first $\mathrm{AI}$; PY $=$ peak milk yield; $\mathrm{PT}=$ time of peak yield: $\mathrm{MPER}=$ milk persistency; $\mathrm{MYFI}=$ milk yield at the first-AI date; MY305 $=305$-d milk yield; PROT305 $=305$-d protein yield; FAT305 $=305$-d fat yield

${ }^{3}$ Ref. $=$ reference category

${ }^{4}$ Categorized data not shown.

${ }^{5} \mathrm{NS}=P>0.1$.

of SFI with PY, MPER, MYFI, MY305, 305-d protein yield, 305-d fat yield, CFI, breed, parity, calf status, AI time related to $\mathrm{PT}$, month of calving, and month of first AI were statistically significant for each individual variable (Table 2).

\section{Multivariable Logistic Regression Model}

Results of the final multivariable logistic regression model are given in Table 3, and the associations between SFI and independent categorized factors and their interactions are plotted in Figures 1, 2, 3, and 4 . The random effect of farms was small, $\lambda$ being 0.06 (SE 


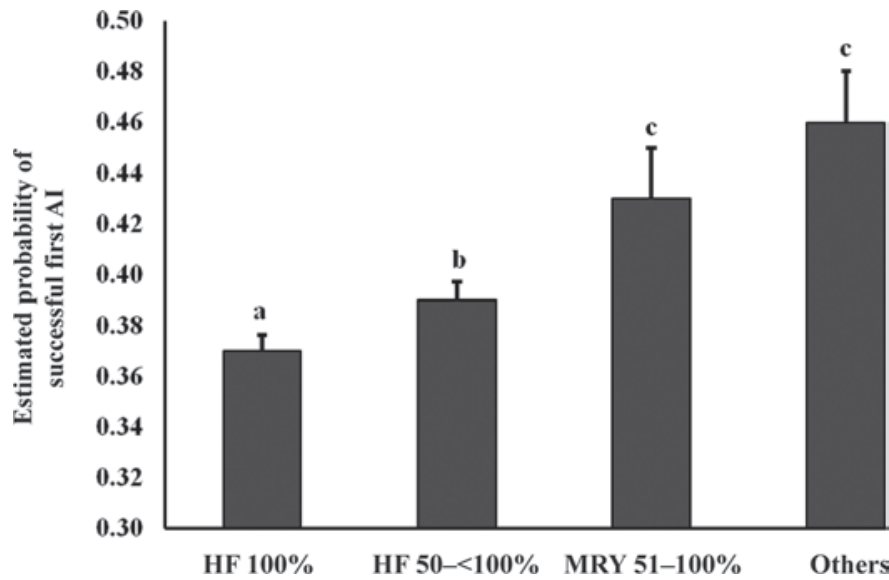

Figure 1. The estimated probabilities of successful first AI in different breeds correcting for other factors in the final multivariable logistic regression model. The letters $\mathrm{a}, \mathrm{b}$, and $\mathrm{c}$ indicate differences $(P$ $<0.05)$ of estimated probability of successful first AI between breeds $(\mathrm{HF}=$ Holstein-Friesian; $\mathrm{MRY}=$ Dutch Red-and-White $)$

$=0.007)$. No confounding was found, and the inspection of residual plots showed no irregularities.

The MYFI had an effect on SFI depending on CFI (Table 3). When cows were artificially inseminated be-

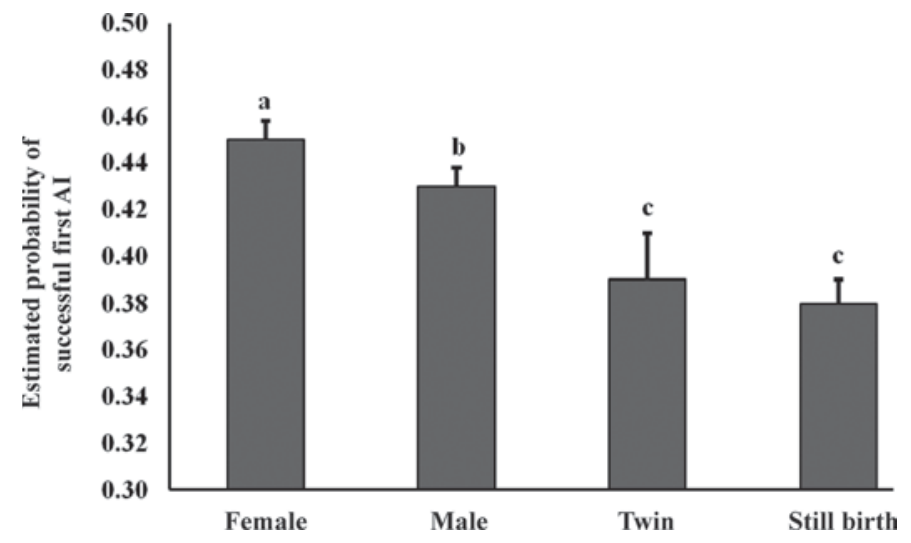

Figure 2. The estimated probabilities of successful first AI in different calf statuses correcting for other factors in the final multivariable logistic regression model. The letters a, b, and c indicate differences $(P<0.05)$ of estimated probability of successful first AI between calf statuses.

fore 60 DIM, the increase of MYFI had less of an effect on SFI, but a high level of MYFI reduced SFI for cows that were artificially inseminated after 60 DIM. Moreover, cows that were artificially inseminated before PT had a significantly (odds ratio $=0.8 ; P<0.01$ ) lesser

Table 3. Results of the analysis of risk factors for successful first AI from the multivariable logistic regression analysis using farm as a random effect in the model $(\lambda=0.06, \mathrm{SE}=0.007)^{1}$

\begin{tabular}{|c|c|c|c|c|}
\hline Variable $^{2}$ & $\beta$ & $\mathrm{OR}^{3}$ & $\begin{array}{l}95 \% \text { CI } \\
\text { for OR }\end{array}$ & $P$-value \\
\hline Intercept & 0.23 & & & \\
\hline Breed & & & & $<0.01$ \\
\hline HF $100 \%$ & Ref. $^{4}$ & 1 & & \\
\hline HF 50 to $<100 \%$ & 0.09 & 1.10 & $1.05-1.14$ & $<0.01$ \\
\hline MRY 51 to $100 \%$ & 0.27 & 1.31 & $1.17-1.47$ & $<0.01$ \\
\hline Others & 0.38 & 1.46 & $1.24-1.73$ & $<0.01$ \\
\hline Calf status & & & & $<0.01$ \\
\hline Female & Ref. & 1 & & \\
\hline Male & -0.06 & 0.94 & $0.90-0.97$ & $<0.01$ \\
\hline Twin & -0.24 & 0.79 & $0.70-0.90$ & $<0.01$ \\
\hline Stillbirth & -0.27 & 0.76 & $0.71-0.81$ & $<0.01$ \\
\hline Time of AI & & & & $<0.01$ \\
\hline Before PT & -0.23 & 0.80 & $0.74-0.86$ & $<0.01$ \\
\hline After PT & Ref. & 1 & & \\
\hline MYFI (kg/d) & -0.02 & & & $<0.01$ \\
\hline MYFI $\times$ CFI & & & & 0.05 \\
\hline $\mathrm{MYFI} \times \mathrm{CFI} \leq 60 \mathrm{~d}$ & 0.02 & 1.02 & $1.00-1.05$ & 0.02 \\
\hline MYFI $\times$ CFI 61 to $81 \mathrm{~d}$ & 0.01 & 1.01 & $1.00-1.03$ & 0.1 \\
\hline MYFI $\times$ CFI 82 to $102 \mathrm{~d}$ & 0.003 & 1.00 & $0.99-1.01$ & $\mathrm{NS}^{5}$ \\
\hline MYFI $\times$ CFI 103 to $123 \mathrm{~d}$ & 0.002 & 1.00 & $0.99-1.01$ & NS \\
\hline $\mathrm{MYFI} \times \mathrm{CFI} \geq 124 \mathrm{~d}$ & Ref. & 1 & & \\
\hline $\mathrm{CFI} \times$ parity $^{6}$ & & & & 0.02 \\
\hline $\mathrm{CFI} \times$ month of $\mathrm{AI}^{6}$ & & & & $<0.01$ \\
\hline
\end{tabular}

${ }^{1}$ The ratio of the generalized chi-squared statistic and its degrees of freedom equals 0.99 , and estimated coefficients $(\beta)$, odds ratio (OR), $95 \%$ CI for OR, and significance level are given for each cow-specific risk factor. ${ }^{2} \mathrm{HF}=$ Holstein-Friesian; MRY $=$ Dutch Red-and-White; CFI = interval from calving to first AI; MYFI = milk yield at the first-AI date; $\mathrm{PT}=\mathrm{DIM}$ at peak milk yield.

${ }^{3}$ Odds ratio for successful first AI versus failure of the first AI.

${ }^{4}$ Ref. $=$ reference category.

${ }^{5} \mathrm{NS}=P>0.1$.

${ }^{6}$ Categorized data not shown. 


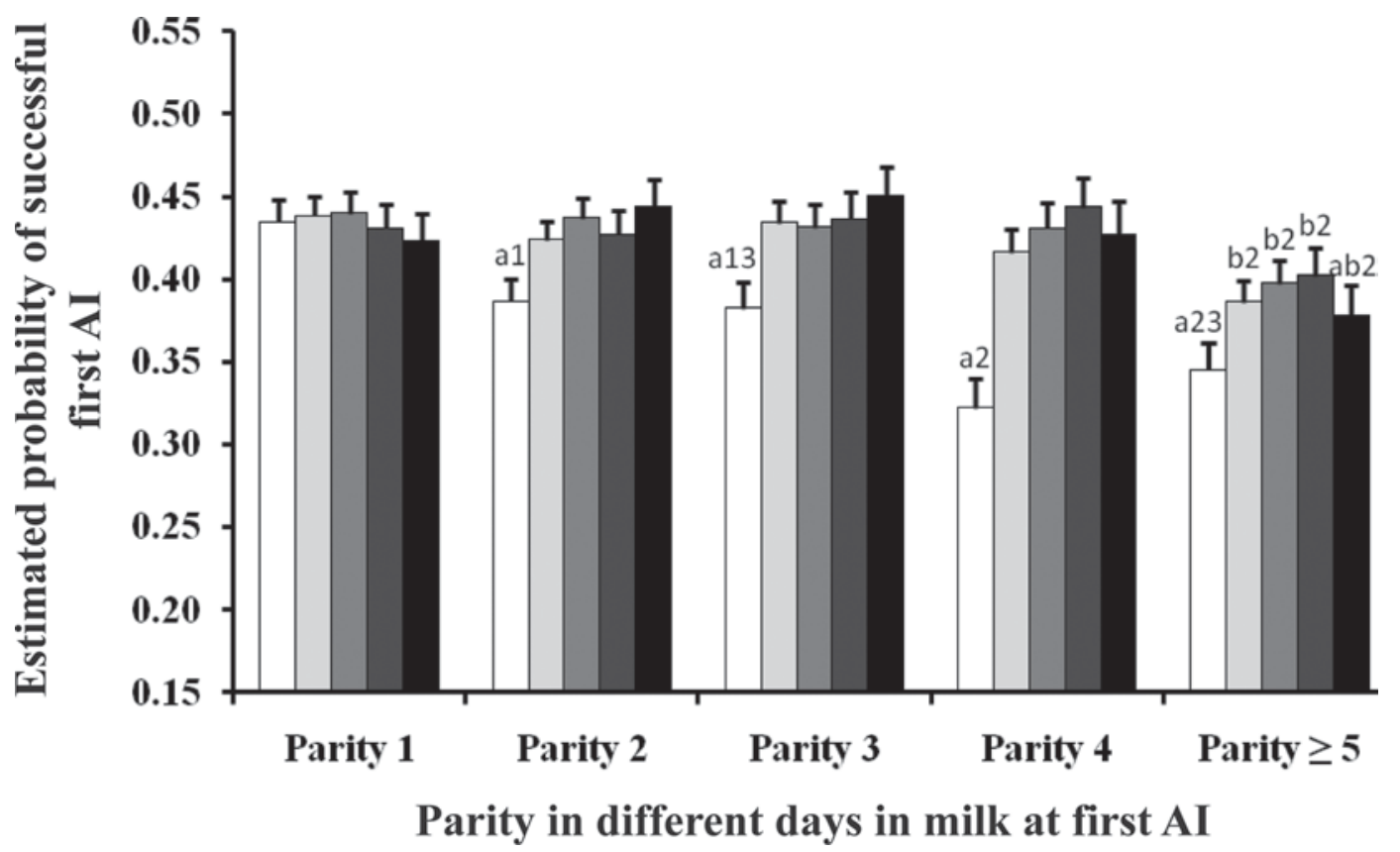

Figure 3. The effect of the interaction of parity and DIM at first AI on successful first AI in the final multivariable model. The differences $(P$ $<0.05$ ) of estimated probability of successful first AI are shown, with a and b indicating the differences between DIM at first AI $[\leq 60 \mathrm{~d}$ (white bars), 61 to $81 \mathrm{~d}$ (light gray bars), 82 to $102 \mathrm{~d}$ (gray bars), 103 to $123 \mathrm{~d}$ (dark gray bars), and $>124 \mathrm{~d}$ (black bars)] within the same parity and 1,2 , and 3 indicating the differences between parities within the same category of DIM.

SFI (0.39) compared with cows that were artificially inseminated after PT $(\mathrm{SFI}=0.44)$.

After adjusting for other factors, SFI was greater for 50 to $<100 \%$ HF cows, 51 to $100 \%$ Dutch Red-andWhite, and other breeds compared with $100 \%$ HF cows
(Table 3 and Figure 1). Calf status had an effect on SFI (Table 3 and Figure 2). With interaction of CFI, extending CFI did not improve SFI in the first-parity cows, but SFI was improved significantly in other parities when the first AI was after 60 DIM (Figure 3). In

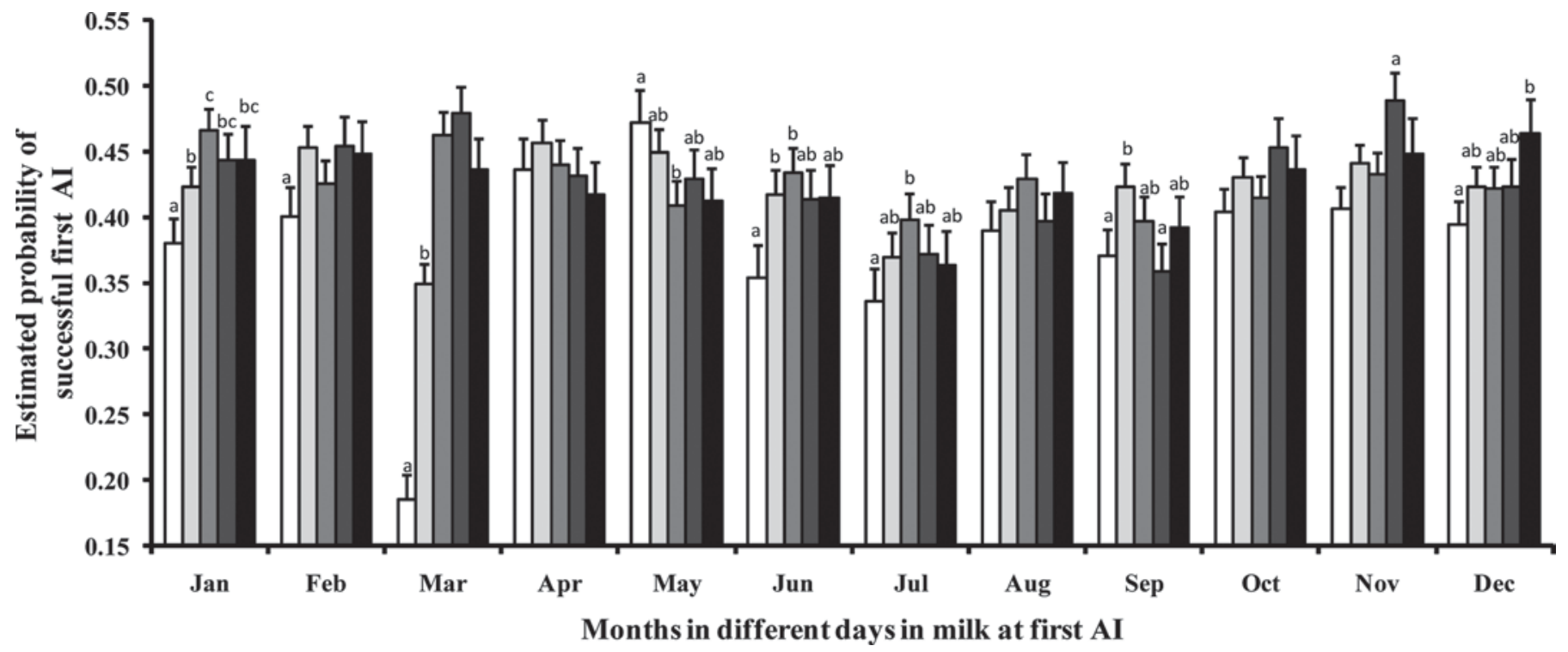

Figure 4. The effect of the interaction of month of AI and DIM at first AI on successful first AI in the final multivariable model. The differences $(P<0.05)$ of estimated probability of successful first AI are shown, with a, b, and c indicating the differences between DIM at first AI [ $\leq 60 \mathrm{~d}$ (white bars), 61 to $81 \mathrm{~d}$ (light gray bars), 82 to $102 \mathrm{~d}$ (gray bars), 103 to $123 \mathrm{~d}$ (dark gray bars), and $\geq 124 \mathrm{~d}$ (black bars)] within the same month of AI. 
comparison with other parities at the same period of CFI after 60 DIM, cows in parity $\geq 5$ had the least SFI and the first-parity cows had the greatest SFI compared with other parities when AI was before 60 DIM.

The interaction of month of first AI with CFI had an effect on the SFI after correction for other factors. The association between SFI and the interaction of month of first AI with CFI is shown in Figure 4. In all months, the SFI was less when cows were artificially inseminated before 60 DIM compared with after 60 DIM. This was particularly true for AI in March before 60 DIM, when SFI was very low and SFI was improved after 81 DIM. In every period of CFI, the AI in summer, especially in July, had the least SFI compared with other seasons.

\section{DISCUSSION}

The percentage of pregnancy after first AI in Dutch dairy cows varied between 40 and $45 \%$ and was dependent on fat and protein-corrected milk yield, parity, postpartum disorders, and BCS (Loeffler et al., 1999). Here, SFI varied depending on breed, parity, calf status, and time to AI. Before 60 DIM, SFI in multiparous cows was less in all months, and SFI increased when CFI was >60 DIM (Figure 3 and 4). The greater SFI at larger CFI may be caused by an improved energy balance (Butler and Smith, 1989; Loeffler et al., 1999). Although other studies did not look at the interaction between MYFI and CFI, other studies suggest amelioration of SFI when the first AI is postponed (Loeffler et al., 1999; Tenhagen et al., 2003). Given the interaction between MYFI and CFI, the results of our study suggest that the negative effect of CFI on SFI is greater for cows that produce more compared with cows that produce less. Insemination after PT resulted in greater SFI than AI before PT. Cows having lesser MYFI in combination with a longer CFI at the same period of CFI showed greater SFI than did cows with high MYFI when the first AI was performed after 60 DIM and especially when these cows were artificially inseminated after PT.

The average SFI in first-parity cows was 41 to $44 \%$, which supports the findings of Windig et al. (2005) that the success of first AI was $46 \%$ in the first parity and $44 \%$ in greater parity cows. As found in other studies, older cows artificially inseminated before 60 DIM were less likely to become pregnant after first AI than younger cows (Eicker et al., 1996; Tenhagen et al., 2003). In contrast to these results, other studies have shown lesser conception rates at the first AI in first-parity cows (Rocha et al., 2001; Melendez and Pinedo, 2007) and have indicated that a more severe negative energy balance due to greater energy requirement for growth may be the explanation (Lucy, 2001). Yet, when the effects of environment and feeding were controlled, the first-parity cows had a lesser negative energy balance and, hence, an improved fertility outcome compared with multiparous cows (Friggens et al., 2007). Results of this study showed that SFI of the first-parity cows when AI was performed during early lactation was not different from that when AI was performed in later stages of lactation (Figure 3). In general, differences between studies are difficult to explain but may be due to different social and nutritional management strategies used on the included cows.

Season is an important factor affecting fertility, both the season of calving (Eicker et al., 1996; Melendez and Pinedo, 2007) and the season of AI (Huang et al., 2009). The effect of DIM on conception rate varied between seasons in our study and in the studies of others (Eicker et al., 1996; Huang et al., 2008). The reason for a somewhat lesser conception rate in summer was explained by the effects of high temperature. Moreover, a lesser SFI at the start and finish of the grazing season may be due to difficulties with regard to the switch between feeding and housing systems. In winter, dairy cows in the Netherlands are housed inside the barn and, in most herds, cows are pastured from April to October.

Our results showed that $100 \% \mathrm{HF}$ cows had lesser SFI compared with cross-bred cows and cows of other breeds. Previous studies have found that a high-milkyield cow has a greater BCS change than a low-milkyield cow (Loeffler et al., 1999; Berry et al., 2003; Buckley et al., 2003) as a result of the mobilization of more body energy in early lactation of the Holstein compared with the Danish Red and Jersey breeds (Friggens et al., 2007). Moreover, a negative correlation between BCS loss and reproductive performance in different breeds is well established (Pryce et al., 2001). It has been suggested that differences between breeds in their ability to partition energy between milk production and body reserves could be responsible for the differences in fertility (Yan et al., 2006; Friggens et al., 2007; Walsh et al., 2008).

Stillbirth and twin calving were associated with the reduction of SFI, which supports other previous studies (Berry et al., 2007). Stillbirth may be caused by dystocia (Chassagne et al., 1999), and dystocia may be caused by twin calving or larger-sized calves, hence a heavier weight. Dystocia negatively affects postpartum reproductive performance (Chassagne et al., 1999). Moreover, cows that experienced stillbirth showed a slightly more severe negative energy balance (Berry et al., 2007), which may contribute to lesser fertility.

The analysis was carried out on an individual cow level, using farm as a random effect, as was done in a recent study (Friggens and Labouriau, 2010), and included culled cows in the statistical calculations. 
Therefore, it is not likely that SFI was overestimated. A potential lesser SFI for cows having postpartum disorders was not studied because data on postpartum disorders were not available. Existing databases were used, and the variation between farms might have biased the results. Farms were included as random effects in our model, which has the advantage of correcting for variation of herd management such as differences in nutritional management and environment. The results showed that the variation in SFI between farms was relatively small. Only one lactation per cow was included in the analysis to prevent a bias from repeated individual cows.

To accurately study the relationship between milk yield and fertility, sick and aborted cows should be deleted from the analysis. Because the data set did not contain information about illness and abortions, the situation allowed selection of only cows that had a nonaberrant fitted milk production curve. The modeled cow factors were all factors that are known at the moment that cows are eligible for AI. At that time, the decision on whether a cow will be inseminated or not and the probability of a successful first AI are important variables. Therefore, these results can be applied in models that support AI decisions. Instead of using a generic voluntary waiting period for all cows in a herd, the voluntary waiting period may be adjusted for individual cows, taking into account cow factors such as the production level, persistency of milk production, and parity.

\section{CONCLUSIONS}

The results show that SFI was influenced by MYFI, CFI, time of AI related to PT, parity, breed, calf status, and season. For multiparous cows, AI in an early lactation stage (before 60 DIM) reduced SFI moderately, but AI in a later stage of lactation and a low MYFI improved SFI. Insemination before peak milk yield reduced SFI. Knowledge of the influence of cow factors that contribute to SFI can be applied when deciding on the moment of AI for individual cows that are in estrus.

\section{ACKNOWLEDGMENTS}

We thank Mathijs van Pelt (CRV, Arnhem, the Netherlands) for his support in preparation of the data set and the Cattle Improvement Co-operative (Arnhem, the Netherlands) for providing the data used in the present study. We thank Jan van Den Broek (Department of Farm Animal Health, Faculty of Veterinary Medicine, Utrecht University, the Netherlands) for his suggestions on the statistics.

\section{REFERENCES}

Berry, D. P., F. Buckley, P. Dillon, R. D. Evans, M. Rath, and R. F. Veerkamp. 2003. Genetic relationships among body condition score, body weight, milk yield, and fertility in dairy cows. J. Dairy Sci. 86:2193-2204.

Berry, D. P., J. M. Lee, K. A. Macdonald, and J. R. Roche. 2007. Body condition score and body weight effects on dystocia and stillbirths and consequent effects on postcalving performance. J. Dairy Sci. 90:4201-4211.

Brown, H., and R. Prescott. 1999. Applied Mixed Models in Medicine. John Wiley and Sons, Ltd., Chichester, UK.

Buckley, F., K. O'Sullivan, J. F. Mee, R. D. Evans, and P. Dillon. 2003. Relationships among milk yield, body condition, cow weight, and reproduction in spring-calved Holstein-Friesians. J. Dairy Sci. 86:2308-2319.

Butler, W. R., and R. D. Smith. 1989. Interrelationships between energy balance and postpartum reproductive function in dairy cattle. J. Dairy Sci. 72:767-783.

Chassagne, M., J. Barnouin, and J. P. Chacornac. 1999. Risk factors for stillbirth in Holstein heifers under field conditions in France: A prospective survey. Theriogenology 51:1477-1488.

Eicker, S. W., Y. T. Grohn, and J. A. Hertl. 1996. The association between cumulative milk yield, days open, and days to first breeding in New York Holstein cows. J. Dairy Sci. 79:235-241.

Friggens, N. C., P. Berg, P. Theilgaard, I. R. Korsgaard, K. L. Ingvartsen, P. Løvendahl, and J. Jensen. 2007. Breed and parity effects on energy balance profiles through lactation: Evidence of genetically driven body energy change. J. Dairy Sci. 90:5291-5305.

Friggens, N. C., and R. Labouriau. 2010. Probability of pregnancy as affected by oestrus number and days to first oestrus in dairy cows of three breeds and parities. Anim. Reprod. Sci. 118:155-162.

Huang, C., S. Tsuruta, J. K. Bertrand, I. Misztal, T. J. Lawlor, and J. S. Clay. 2008. Environmental effects on conception rates of Holsteins in New York and Georgia. J. Dairy Sci. 91:818-825.

Huang, C., S. Tsuruta, J. K. Bertrand, I. Misztal, T. J. Lawlor, and J. S. Clay. 2009. Trends for conception rate of Holsteins over time in the southeastern United States. J. Dairy Sci. 92:4641-4647.

Kadarmideen, H. N., R. Thompson, and G. Simm. 2000. Linear and threshold model genetic parameters for disease, fertility and milk production in dairy cattle. Anim. Sci. 71:411-419.

Kinsel, M. L., and W. G. Etherington. 1998. Factors affecting reproductive performance in Ontario dairy herds. Theriogenology 50:1221-1238

Loeffler, S. H., M. J. de Vries, Y. H. Schukken, A. C. de Zeeuw, A. A. Dijkhuizen, F. M. de Graaf, and A. Brand. 1999. Use of AI technician scores for body condition, uterine tone and uterine discharge in a model with disease and milk production parameters to predict pregnancy risk at first AI in Holstein dairy cows. Theriogenology 51:1267-1284

Lucy, M. C. 2001. Reproductive loss in high-producing dairy cattle: Where will it end? J. Dairy Sci. 84:1277-1293.

Melendez, P., and P. Pinedo. 2007. The association between reproductive performance and milk yield in Chilean Holstein cattle. J. Dairy Sci. 90:184-192.

Muir, B. L., J. Fatehi, and L. R. Schaeffer. 2004. Genetic relationships between persistency and reproductive performance in first-lactation Canadian Holsteins. J. Dairy Sci. 87:3029-3037.

Norman, H. D., J. R. Wright, S. M. Hubbard, R. H. Miller, and J. L. Hutchison. 2009. Reproductive status of Holstein and Jersey cows in the United States. J. Dairy Sci. 92:3517-3528.

Olori, V. E., S. Brotherstone, W. G. Hill, and B. J. McGuirk. 1997. Effect of gestation stage on milk yield and composition in Holstein Friesian dairy cattle. Livest. Prod. Sci. 52:167-176.

Pryce, J. E., M. P. Coffey, and G. Simm. 2001. The relationship between body condition score and reproductive performance. J. Dairy Sci. 84:1508-1515.

Rocha, A., S. Rocha, and J. Carvalheira. 2001. Reproductive parameters and efficiency of inseminators in dairy farms in Portugal Reprod. Domest. Anim. 36:319-324.

Tenhagen, B. A., C. Vogel, M. Drillich, G. Thiele, and W. Heuwieser. 2003. Influence of stage of lactation and milk production on con- 
ception rates after timed artificial insemination following Ovsynch. Theriogenology 60:1527-1537.

Tsuruta, S., I. Misztal, C. Huang, and T. J. Lawlor. 2009. Bivariate analysis of conception rates and test-day milk yields in Holsteins using a threshold-linear model with random regressions. J. Dairy Sci. 92:2922-2930.

Veerkamp, R. F., E. P. Koenen, and G. De Jong. 2001. Genetic correlations among body condition score, yield, and fertility in firstparity cows estimated by random regression models. J. Dairy Sci. 84:2327-2335.

Walsh, S., F. Buckley, K. Pierce, N. Byrne, J. Patton, and P. Dillon. 2008. Effects of breed and feeding system on milk production, body weight, body condition score, reproductive performance, and postpartum ovarian function. J. Dairy Sci. 91:4401-4413.

Wilmink, J. B. M. 1987. Adjustment of test-day milk, fat and protein yield for age, season and stage of lactation. Livest. Prod. Sci. $16: 335-348$.

Windig, J. J., M. P. Calus, and R. F. Veerkamp. 2005. Influence of herd environment on health and fertility and their relationship with milk production. J. Dairy Sci. 88:335-347.

Yan, T., C. S. Mayne, T. W. J. Keady, and R. E. Agnew. 2006. Effects of dairy cow genotype with two planes of nutrition on energy partitioning between milk and body tissue. J. Dairy Sci 89:1031-1042. 